\title{
ERRATUM
}

\section{Erratum to: $n a b$-Paclitaxel Plus Gemcitabine Versus Gemcitabine in Patients with Metastatic Pancreatic Adenocarcinoma: Canadian Subgroup Analysis of the Phase 3 MPACT Trial}

\author{
Mustapha Tehfe $\cdot$ Scot Dowden · Hagen Kennecke · Robert El-Maraghi • \\ Bernard Lesperance $\cdot$ Felix Couture · Richard Letourneau · Helen Liu • \\ Alfredo Romano
}

Published online: November 24, 2016

(c) The Author(s) 2016. This article is published with open access at Springerlink.com

Erratum to: Adv Ther (2016) 33:747-759

DOI 10.1007/s12325-016-0327-4

The authors would like to correct the errors in Table 1 and text in the published article. The correct table and the text should read as below.

The online version of the original article can be found under doi:10.1007/s12325-016-0327-4.

M. Tehfe $(\varangle) \cdot$ R. Letourneau

Centre hospitalier de l'université de Montréal

(CHUM), Montreal, QC, Canada

e-mail: mustapha.tehfe.chum@ssss.gouv.qc.ca

S. Dowden

Tom Baker Cancer Centre, Calgary, AB, Canada

H. Kennecke

British Columbia Cancer Agency, Vancouver, BC, Canada

R. El-Maraghi

Royal Victoria Regional Health Centre, Barrie, ON, Canada

B. Lesperance

Hôpital du Sacré-Coeur de Montreal, Montreal, QC, Canada

F. Couture

Centre hospitalier universitaire de Québec (CHUQ),

Hôtel-Dieu de Quebec, CHUM, Montreal, QC,

Canada

H. Liu · A. Romano

Celgene Corporation, Summit, NJ, USA
In Table 1, the numbers for the intent-to-treat population for biliary stent and previous Whipple procedure were erroneously switched. Table 1 should appear as below.

The corresponding text for Table 1 under the Baseline Characteristics heading in the Results section should read, "Fewer patients in the Canadian cohort had a KPS of 100 than in the ITT population," i.e., removing "or previous Whipple procedure" from the original sentence which read "Fewer patients in the Canadian cohort had a KPS of 100 or previous Whipple procedure than in the ITT population."

Under the Statistical Analyses section, the second-to-last sentence reads "A nonstratified log-rank test was PFS between the treatment arms, and the HR and two-sided 95\% CIs were estimated by a Cox proportional hazards model." It should read "A stratified log-rank test was used to compare PFS between the treatment arms, and the HR and two-sided 95\% CIs were estimated by a Cox proportional hazards model."

In the Discussion (last paragraph beginning at the bottom of page 756), the sentence reads, "Health Canada has approved nab-P + Gem and FOLFIRINOX for the treatment of patients with 
Table 1 Baseline characteristics

\begin{tabular}{|c|c|c|c|}
\hline \multirow[t]{2}{*}{ Variable } & \multicolumn{2}{|l|}{ Patients in Canada } & \multirow{2}{*}{$\begin{array}{l}\text { ITT population [9] } \\
(N=861)\end{array}$} \\
\hline & $n a b-\mathrm{P}+\mathrm{Gem}(n=33)$ & $\operatorname{Gem}(n=30)$ & \\
\hline Age, median (range), years & $61.0(34-77)$ & $61.5(49-72)$ & $63.0(27-88)$ \\
\hline \multicolumn{4}{|l|}{ Sex, $n(\%)$} \\
\hline Female & $12(36)$ & $9(30)$ & $359(42)$ \\
\hline Male & $21(64)$ & $21(70)$ & $502(58)$ \\
\hline \multicolumn{4}{|l|}{$\mathrm{KPS}, n(\%)$} \\
\hline 100 & $2(6)$ & $3(10)$ & $138(16)^{\mathrm{a}}$ \\
\hline 90 & $18(55)$ & $14(47)$ & $378(44)^{\mathrm{a}}$ \\
\hline 80 & $9(27)$ & $12(40)$ & $277(32)^{\mathrm{a}}$ \\
\hline 70 & $4(12)$ & $1(3)$ & $63(7)^{\mathrm{a}}$ \\
\hline 60 & 0 & 0 & $2(<1)^{\mathrm{a}}$ \\
\hline \multicolumn{4}{|c|}{ Number of metastatic sites, $n(\%)$} \\
\hline 1 & $4(12)$ & $1(3)$ & $54(6)$ \\
\hline 2 & $11(33)$ & $11(37)$ & $408(47)$ \\
\hline$\geq 3$ & $18(55)$ & $18(60)$ & $399(46)$ \\
\hline \multicolumn{4}{|l|}{ Sites of metastases, $n(\%)$} \\
\hline Liver & $27(82)$ & $25(83)$ & $725(84)$ \\
\hline Lung & $14(42)$ & $18(60)$ & $337(39)$ \\
\hline Peritoneum & $2(6)$ & $1(3)$ & $29(3)$ \\
\hline \multicolumn{4}{|c|}{ Pancreatic tumor location, $n(\%)$} \\
\hline Head & $18(55)$ & $9(30)$ & $371(43)$ \\
\hline Body & $11(33)$ & $11(37)$ & $268(31)$ \\
\hline Tail & $4(12)$ & $10(33)$ & $215(25)$ \\
\hline Unknown & 0 & 0 & $7(1)$ \\
\hline \multicolumn{4}{|l|}{ CA $19-9, n(\%)$} \\
\hline Normal & $3(9)$ & $3(10)$ & $116(15)^{b}$ \\
\hline$>\mathrm{ULN}$ and $<59 \times \mathrm{ULN}$ & $11(33)$ & $11(37)$ & $242(32)^{b}$ \\
\hline$\geq 59 \times \mathrm{ULN}$ & $16(48)$ & $11(37)$ & $392(52)^{b}$ \\
\hline Unknown & $3(9)$ & $5(17)$ & $111(13)^{\mathrm{c}}$ \\
\hline Biliary stent, $n(\%)$ & $11(33)$ & $8(27)$ & $148(17)$ \\
\hline
\end{tabular}


Table 1 continued

\begin{tabular}{|c|c|c|c|}
\hline \multirow[t]{2}{*}{ Variable } & \multicolumn{2}{|l|}{ Patients in Canada } & \multirow{2}{*}{$\begin{array}{l}\text { ITT population }[9] \\
(N=861)\end{array}$} \\
\hline & $n a b-\mathrm{P}+\mathrm{Gem}(n=33)$ & $\operatorname{Gem}(n=30)$ & \\
\hline Previous Whipple procedure, $n$ (\%) & $3(9)$ & $2(7)$ & $62(7)$ \\
\hline
\end{tabular}

CA 19-9 carbohydrate antigen 19-9, Gem gemcitabine, ITT intent-to-treat, KPS Karnofsky performance status, nab-P nab-paclitaxel, ULN upper limit of normal

a Total evaluable patients $=858$

b Total evaluable patients $=750$

c This value was not reported in Ref. [9]

MPC based on the phase III MPACT and PRODIGE trials (ClinicalTrials.gov identifier, NCT00112658), respectively, in which $n a b-\mathrm{P}+\mathrm{Gem}$ and FOLFIRINOX demonstrated superior efficacy vs. Gem alone [4, 9, 20]." It should read, "Based on the results of the phase III MPACT and PRODIGE trials (ClinicalTrials.gov identifier, NCT00112658), both the $n a b-\mathrm{P}+\mathrm{Gem}$ and FOLFIRINOX regimens are accessible in Canada; however, Health Canada only reviewed and approved $n a b-\mathrm{P}+\mathrm{Gem}$ for the first-line treatment of MPC $[4,7,9,20] . "$
Open Access. This article is distributed under the terms of the Creative Commons Attribution-NonCommercial 4.0 International License (http://creativecommons.org/licenses/ by-nc/4.0/), which permits any noncommercial use, distribution, and reproduction in any medium, provided you give appropriate credit to the original author(s) and the source, provide a link to the Creative Commons license, and indicate if changes were made. 